\title{
HOW THE NEW LEGAL AID SERVICE WORKS IN ENGLAND
}

\author{
JAMES Avery Joyce*
}

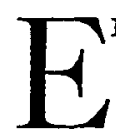

NGLISH LAWYERS WILC ASSENT WHOLEHEARTEDLY to the view expressed by Emery A. Brownell, in an excellent article entitled "Legal Aid and Democracy," which appeared some three years ago in the Cornell Law Quarterly, ${ }^{1}$ that Legal Aid "is a practicable, realistic means of providing equal justice under law, and this is basic to our democratic system." But members of the English Bar, who are also close students of Anglo-American jurisprudence, have more recently been somewhat dismayed by the attitude taken up-obviously in ignorance of what has been happening in England-by some of their colleagues across the Atlantic with regard to the character of the new Legal Aid Service which, thanks to the initiative and cooperation of the whole legal profession, has now been in successful operation for well over a year. It is important, from both points of view, for any such misunderstandings to be cleared up as quickly as possible. As Robert Abrahams, Chief Counsel to the Legal Aid Service of Philadelphia, has said in referring to the operation of the new English Legal Assistance Plan, "The vastness of that enterprise cannot be easily grasped by those accustomed to the usual local Legal Aid or Legal Reference set-up. Its impact on American legal thought can hardly be estimated at this time."2

As an instance of the attitude which English practitioners may well find bewildering, the present writer ventures to quote the following passage from an otherwise constructive article by Mr. Orison S. Marden, Chairman of the Standing Committee on Legal Aid Work of the American Bar Association:

The recent adoption of the English Legal Aid and Adrice Act has aroused lawyers and laymen alike to the importance of providing legal aid facilities on a voluntary local basis. Nothing could more surely hasten the downfall of America than the loss of our independent fearless bar. History records that subjugation of the legal profession is one of the first steps taken by the dictator or totalitarian state in order to enslave the people. How long could the bar be expected to maintain its independence if lawyers should become, in effect, hired hands of the state, subject to bureaucratic control?3

* Barrister-at-Law of the Inner Temple and of the South-Eastern Circuit.

${ }^{1} 34$ Cornell L. Q. 580 (1949).

2 NLAA, 9 Brief Case, No. 1 (1950).

${ }^{3}$ NLAA, 9 Brief Case, No. 2 (1950). 
Phrases such as "subjugation of the legal profession" and "hired hands of the state," coupled directly with the English Legal Aid Act, would tend to provoke in the mind of the English practitioner serious doubts as to whether the "crisis of confidence" (as one well-known publicist in Washington has described it in the British press) through which the United States now seems to be passing had not overspilled from the political to the judicial plane. The spectacle of a "fearless bar" rushing to the aid of poor persons, not because of the merits of their case, but because only thus could the "independence of lawyers" be maintained against "bureaucratic control," would appear to the English practitioner as somewhat of an overstatement-at least so far as recent experience in Great Britain is concerned. Knowing, as he does, that the new Legal Aid Service is not only largely the voluntary creation of the legal profession, but that Parliament has entrusted its full control and administration to the legal profession itself, the English practitioner might be excused for asking how it could ever come about that it would hasten the "downfall of America" for Chief Justice Hughes' constant emphasis on "the equal protection of the laws" to be applied in the United States as it is in England?

Let it be stated at once that, not only is it an axiom of the new service in England that the whole working of the Act is handed over, nationally, regionally and locally to the existing professional associations of lawyers, but that, when the Act came into effect in October, 1950, four-fifths of the legal profession had already, by individual and voluntary application, enlisted in the scheme. None other than the Chairman of the General Council of the Bar, a distinguished and respected advocate who was recently the guest of the American Bar Association, sponsored the new Service in the following forthright words:

Agreat trust has been imposed in us by Parliament and the country, and I am confdent that, as a profession, we shall demonstrate that that trust has been well placed.

In short, anything more remote from the action of a "dictator or totalitarian state" taken to "enslave the people" would be difficult to conceive. Without, therefore, commenting further on the strictures we have cited, let us proceed to examine the recent English developments in sufficient detail to appraise them on their merits-and "without prejudice."

\section{The Past and the Present}

On the 2nd of October, 1950, the Legal Aid Act, ${ }^{4}$ passed by Parliament in 1949, was brought into operation-at least, in part. When it is in full operation, it will make the courts of the land open to all, irrespective of income or wealth, wherever the applicant has a right to be vindicated. As

‘ Iegal Aid and Advice Act, 12 \& 13 Geo. VI, c. 51 (1949). 
is customary in this country, sweeping reforms of this character are preceded by a long gestation period, during which all interests and parties affected have an adequate chance to be heard. The Rushcliffe Report of $1945^{5}$ was, by and large, embodied in the 1949 Legal Aid Act; which has thus resulted from the thorough investigation which Lord Rushcliffe and his fellow Commissioners had made during the War years.

There is surely no need, in this article, to argue the general case for Legal Aid. "It is so obvious," says Dean Roscoe Pound, "that we have almost ceased to remark it, that in petty causes - that is, with respect to the everyday rights and worongs of the great majority of the urban communitythe machinery whereby rights are secured practically defeats rights by making it impracticable to assert them when they are infringed." Yet, Magna Carta proclaimed: "To no man will we deny, to no man will we sell, or delay, justice or right"; and, as far back as a statute of Henry VII, in 1494, we can read: "Every poor person shall have writ or write . . . according to the nature of their causes, therefor paying nothing to your Highness for the Seals of the same, nor to any person for the writing of the same writ or writs; . . . and the Lord Chancellor shall assign . . . learned counsel and attorneys for the same without any reward taking thereof."

Undoubtedly, the best contemporary analysis published in Britain of the problem of the litigant of small or moderate means is Robert Egerton's "Legal Aid"6 to which the reader is referred for a most painstaking and comprehensive survey of the position then prevailing in many leading countries. Similarly, from the United States, the periodical publications of the National Legal Aid Association, ${ }^{7}$ to which reference has already been made, are beyond praise.

To sum up, then, the development of legal aid in England, leading up to the new Service, the end of the 19th century saw a few scattered centers established by social clubs and other charitable organizations, where poor people could come to have their legal problems looked into and dealt with by professional lawyers, giving their services on a volunteer roster. An unofficial body was set up by voluntary effort in 1929 and called the Bentham Committee (which was disbanded on the coming into being of the new machinery); and this Committee, by means of a roster of barristers and solicitors, greatly improved the services of Poor Man's Lawyers in London. More important, however, was the establishment in

6 Rushcliffe, Report on Legal Aid \& Advice in England and Wales, Cmd. 6641 (1945).

- Egerton, Legal Aid (1946).

${ }^{7}$ Address: 328 Main Street East, Rochester 4, New York. See also the ample footnote references on legal aid documentation in the United States appearing in Brownell, op. cit. supra note 1. 
1914, under Rules of the Supreme Court, of the "Poor Persons' Procedure." This Procedure enabled many thousands of poor persons' actions to be taken in the High Court in the same way as if fees had been paid; but, in all these cases, the barristers and solicitors who have done the work have received no remuneration whatever. Only at the end of the War, by the institution of a "Services Divorce Department," which handled over 30,000 such cases within a few years, was a concession made to the practitioner, and a very small fee paid for these cases from state funds.

But, from the applicant's point of view, there were two severe limitations to this Procedure. First, it was confined to those whose present income did not exceed $\$ 5.60 \dagger$ or, in special circumstances, $\$ 11.20$ weekly, and who did not possess more than $\$ 140$ worth of personal property. Secondly, it only applied to High Court Actions. Although it is true that the County Courts enjoy in England, when all is said and done, a high reputation for their efficiency and fairness, as well as for their inexpensiveness, it is the exceptions which make hard cases; and, as the initial court fees are not usually the main obstacle, there must inevitably be a large number of would-be litigants who cannot risk the costs of proceedings even in these "cheap" courts. On the criminal side, the value of the immemorial "dock brief" to many unfortunate prisoners cannot be overlooked; nor the powers given to judges and magistrates under the Poor Prisoners' Defence Act (1930) to provide the accused with solicitor and counsel in suitable cases.

Finally, when it comes to a matter of legal advice, the day-to-day activities of many hundreds of Citizens' Advice Bureaux (many of which manage to secure the voluntary attendance of a qualified lawyer during certain hours) have made a large contribution by helping the poor person with legal problems. But, excellent though this ad hoc service has been, it is deficient as a permanent scheme of legal aid, since advice by itself is often inadequate to assist a person in a legal difficulty. For example, the Bureaux cannot usually write on the enquirer's behalf a "lawyer's letter" to outsiders. As the 1949 Act comes fully into effect, these maid-of-allwork CAB's will generally be replaced by Legal Aid Centres, under the supervision of local government authorities; and these Centres will be properly equipped to follow through deserving cases and will be staffed by a part-time roster of solicitors.

In passing, it must be recalled that, in England, the legal profession keeps its two branches-barristers and solicitors (or attorneys)-rigidly

$\dagger$ The exchange, based on the devaluated pound, considerably underestimates the maximum income allowed during the period surveyed. [Ed.] 
apart. The former specialize in particular branches of the law in "chambers" or act as advocates in the Superior Courts; while the latter work in offices in direct contact with lay clients, preparing "briefs" and other documents for the barristers, though, in a growing number of cases today, they also appear in person to represent their clients in the Inferior Courts. Solicitors have no right of audience in the Superior Courts. Barristers have a right of audience in all courts, including the House of Lords; but they must never appear in any court without "instructions" from and accompanied by a solicitor (or, in some cases, the latter's clerk). It may surprise American lawyers to learn that, according to a recent Bar Council enquiry (for there is only one Bar "association" in England) it was found that there are barely 2,000 barristers actually practising in the Superior Courts in London today. So the English Bar is a very concentrated profession and is almost entirely centered in London, compared with the solicitors, whose firms are to be found in every town and hamlet. ${ }^{8}$

\section{How America Sees IT}

Two observations might, with some trepidation, be ventured here, by way of rough comparison, concerning the legal aid position in the United States, insofar as it has come to the author's casual notice during several journeys across the States. It need hardly be remarked that Americans are far more litigious than the British; and there may be more than a grain of truth in the wisecrack: "Americans are law-loving; the British are lawabiding."

Firstly, there are provisions whereby attorneys who are admitted to practice in the federal courts may be assigned to represent a person under criminal indictment, for which the attorney so assigned receives no remuneration from the federal government and, if the party is unable to pay, receives nothing, regardless of the time spent in the defence. There is also, in some places, state legal aid, working in conjunction with the bar associations and the Community Chest, though this work is mainly volunteer so far as counsel are concerned. In some of the bigger cities the voluntary organization of legal aid is more systematically done than in

\footnotetext{
${ }^{8}$ I would reluctantly point out that, in the most useful article by Emery A. Brownell, ibid., the statement that the English scheme "would provide a complete legal service both in and out of court under the direction of the Law Society which constitutes the organised bar in England," is not accurate. (Emphasis added.) The Law Society of England is a body constituted by Act of Parliament to have control over the admission, organization and discipline of the solicitors (who form the junior branch of the legal profession); and is quite distinct from the General Council of the Bar, elected annually by the barristers (the senior branch), which is a more informal nonstatutory body drawing its authority from immemorial convention and the prestige of its members.-J. A. J.
} 
England under the voluntary system already described. As the prominent American advocate of Legal Aid, whom we have already quoted, has pointed out:

The changing conditions of modern society require far more than the efforts of individual practitioners. Under present conditions, except in rural areas, the only effective method of meeting the proven need is through a community law office, usually known as the legal aid society. Such an agency, operated by lawyers, but directed and supported by all elements of the community, is the American way of assuring equality before the law to those who cannot pay a lawyer to protect their legal rights.

But it must be admitted that, whereas the limited facilities in England were evenly distributed, the immense area to be covered and the varying jurisdictions in the United States have led to greater disparity. This has generally meant that wealthier communities have provided better services than poorer ones-where, of course, the need is greater.

Nevertheless, the National Legal Aid Association, established under a similar name about 1923, has obviously had a very beneficial effect in increasing and improving such facilities in the United States. Also, by reason of its example, the NLAA has stimulated a greater public and private effort in other countries. Some local Bar Associations, too, have played a considerable part in improving the legal services to the poorer class of client. The size and importance of this extremely valuable public service cannot be better appreciated than by glancing at the bibliography of material relating to legal aid work published by the NLAA. The following excerpts from a recent report $t^{10}$ of the Association gives a fair picture of the progress made:

Organized legal aid is a relatively young concept and a growing acceptance of its usefulness is evident in more communities each year. As of June 1948 there were 152 legal aid organizations in the United States, an increase of 20 organizations over those in 1946. A number of legal aid offices opened their doors as a result of the current promotional campaign begun in $\mathbf{1 9 4 6}$ by the American Bar Association through its Committee on Legal Aid Work. ... The New York Legal Aid Society is now the largest such society in the country with a case load of over 30,000 a year. The Chicago Society developed into the Legal Aid Bureau of the United Charities of Chicago, which now employs 12 full-time attorneys and advises 15,000 new clients each year.

Secondly, as regards criminal cases, a public institution for which there is no exact parallel in England, namely the Public Defender, financed by state funds, exists in a few states and is performing a highly necessary function. In the United States, the procedure appears to be somewhat as follows: (1) The District Attorney issues a complaint which brings the

${ }^{2}$ Marden, NLAA, 9 Brief Case, No. 2 (1950).

${ }^{10}$ Social Work Year Book (1949). 
accused into court; (2) the accused is arraigned, told of the charges against him and, if he is without means to defend himself, the court itself appoints the Public Defender to prepare the defense; (3) before the Superior Court he pleads his case before a jury or, in certain circumstances, without a jury. It is confidently asserted that the Public Defender system saves the taxpayer twice its cost to the community.

The term "assigned counsel" is the nearest English equivalent to Public Defender. But such counsel in England are members of the Bar in ordinary practice, whose names appear on the lists of the criminal courts where they normally practice as being willing to defend, frequently at short notice and for a nominal fee, paid by the court, impecunious prisoners who apply for legal aid on being arraigned. Doubtless the provision of the Public Defender in the United States owes its origin to the protection guaranteed in both federal and state constitutions to individual rights. It appears that Los Angeles was, in 1914, the first city to appoint such an officer, and that city has now twenty deputy Public Defenders. The Public Defender does not interfere, of course, with the District Attorney or the law-enforcement agencies, as he does not come into the case until each of these has gathered his facts. He is appointed at the preliminary hearing but, unlike his English counterpart, cannot engage in private practice.

\section{How tHe New Act WORKS}

Reverting, now, from this excursion in comparative legal aid as a necessary background to our main theme, the English would seem to have jumped over some of the intermediate stages of a well-organized legal aid service on a voluntary basis, such as appears to have been set up in some U.S. local communities, to a streamlined service covering, in some form or another, when brought fully into effect, practically a hundred percent of the population who require it. The age-long principle of "equality of man" is thus in process of being transferred from the sphere of lip service to that of daily practice in the English courts.

The control and administration of the new Act, as we have stressed already, has been handed over entirely to the legal profession. The solicitors' branch, through its professional association, the Law Society, has most of the "office" work to do, naturally; but barristers are directly associated with all the units of machinery described below. There have been constituted by the Law Society and the Bar Council, jointly, twelve areas in England and Wales, each with an Area Committee; and, within these areas, 112 Local Committees have been set up throughout the country to receive and examine applications from persons who desire assistance. 
Practicing barristers and solicitors are entitled to have their names entered on area panels, as being willing to undertake assisted cases; but no practitioner is compelled in any way to do so, and he may resign at any time. It is interesting to record that, up to the time of writing, over eighty-five per cent of the practitioners have joined one or more of these area panels. Under the leadership of the Bar Council itself-which has, since the end of the War, been increasingly concerned with social and legal reforms-it has become a matter of vocational obligation rather than personal gain for the legal profession to assist the government in a great number of social undertakings, of which legal aid is the latest and, perhaps, the most conspicuous example.

The new Act, however, makes no changes in the general organization or etiquette of the legal profession as such, though it will undoubtedly result in the expansion of both branches of the profession when it is fully implemented. It is not possible at this early stage to foresee how large this increase will be; though some authorities have estimated that, were the whole Act to be put in force at once, there would be about 60,000 additional cases coming "into the lists," within the next year or two. Whether this is an over or under-estimate, no one can say. ${ }^{11}$ It is the primary rule of Bar morality that payment of counsel should not be affected by the result of a case, and this principle also is carefully maintained under the new legislation.

Perhaps the one vital difference which does exist between normal cases and the assisted ones, is that, in the latter, there can be no bargaining for a fee between client and lawyer. In assisted cases, the appropriate fee is assessed by an expert on the staff of the Law Courts- "taxing masters" as they are termed. When a reasonable fee has thus been fixed, counsel and solicitors are paid eighty-five percent of this out of the national fund. So, in effect, the Legal Aid lawyer is himself contributing fifteen percent of his normal fees to the fund.

11 The following excerpts from a speech of the Lord Chancellor on the Woolsack in the House of Lords on 20th March, 1952, are significant:

"The 112 certifying committees of the Law Society in the first year of the Act's operation held no fewer than 2,500 meetings. ... Close on 68,000 applications have been considered and 40,000 of these have been given certificates. It is true that the cases take some little time in being considered, but 2,500 cases in which certificates had been given had come to judgment in the year in question. Of those 2,500 , to give an approximate figure, 88 per cent. were successful. It is true that a large proportion of the cases were matrimonial cases in which there was no defence, so that I should not put the figure as high as 88 per cent. in all classes of cases; but of cases that went to the Queen's Bench Division, 70 per cent. were successful and others were settled, and when cases are settled it is generally in favour of the assisted person. I think we can come to no other conclusion than that the Act has been administered carefully and skillfully." 
The net annual cost to the British Treasury cannot be easily assessed, at this stage; but a million pounds has been suggested as a reliable figure for the first year's working. ${ }^{12}$ What is obvious, of course, is that several thousands of cases will certainly be won, or settled out of court, by persons of small means, against their wealthier opponents, especially corporations and government departments-wrongs which would have gone without redress under the old order. It should be remembered, too, that many reluctant suitors are brought into the civil courts for no fault of their own; or they are compelled to suffer injustices silently, by reason of their not being able to take the risks involved in contesting their rights. Nothing is more terrifying and hazardous to the little man than litigation. It is not rash to claim that rarely has so beneficial a social service been instituted at so little public cost.

\section{Who MAY Apply?}

Among the few special types of cases for which legal aid is not available, are proceedings in respect of defamation of character and breach of promise of marriage. But, with these statutory exceptions, any applicant who, in the view of the Local Committee-from whose decision he may appeal to the Area Committee-can show that he has reasonable grounds for taking or defending legal proceedings, is entitled to legal aid, if his "disposable income" is not more than $\$ 1176$ a year (about $\$ 22.40$ a week), and if he possesses not more than $\$ 1400$ of "disposable capital." That is the position in a nutshell.

Now we come to some details. The word "disposable" is important. It must suffice here to explain that considerable allowances may be deducted from an applicant's gross income, if they are regular commitments, such as rent and rates, income tax, maintenance of dependents, and other "unavoidable" outgoings. The same kind of generous allowances apply to the maximum capital permitted. Thus, the above ceiling figures may, in practice, be greatly exceeded; for example, persons enjoying a gross income of $\$ 2800$ a year may come within the scheme. But the delicate and intricate duty of eliciting "disposable income" is not the task of the local Committees-who are chiefly concerned with the legal issues-but of the National Assistance Board, a national department whose local offices have been

12 Ibid. "The costs up to date have, of course, been nothing like what was anticipated. . . In the current year, which runs from April 1 to March 31, the cost is expected to be about $£ 212,000$, but that will very rapidly increase. Again, it is estimated that in a full year the cost will be something like $£ 1,500,000$. That is an estimate, and it is only an estimate. Of course, that is a figure which would be greatly reduced if the fashion of divorce were in any way diminished!" 
charged to assess "disposable" income and capital and report back the position to the Local Committee.

Yet there is one very important further hurdle to be surmounted before a grant is made. If the assisted person's "disposable income" is less than $\$ 8.40$ a week and his "disposable capital" less than $\$ 210$, legal aid is available entirely free. If, however, he has more than this, he will be asked to pay a contribution towards the costs incurred. The actual contribution he will be asked to pay will depend on the cost of his proceedings; but he may be called on to contribute up to a maximum amount as follows: (a) a contribution not greater than half the amount by which his "disposable income" exceeds $\$ 8.40$ a week, and (b) a contribution not greater than the amount by which his "disposable capital" exceeds $\$ 210$. In appropriate cases this contribution will be payable into the Legal Aid fund by instalments. ${ }^{13}$

If both the reasonableness of the claim and the income limits are found to be satisfactory, and if, in the appropriate cases, the applicant accepts the proposal as to his contribution, the local committee issues a "civil aid certificate." This certificate enables the applicant to choose from the relative panels-with one inconsiderable exception-his own lawyer (solicitor or both solicitor and counsel) and proceed with his case in every way as though he were paying for everything out of his own pocket. Where the proceedings are successful, the losing side (who, incidentally, may also be an assisted party) is under the same obligations, as regards payment to the winner of costs and (if awarded) damages, as in a normal case. Where unsuccessful, the maximum payment to be made by the assisted litigant is to be that proportion of the costs which the court decides reasonable in all the circumstances.

This means that, before a case begins, the assisted plaintiff knows what his commitments will be and, if he does not like the look of the deal, he need not embark on the lawsuit at all. It also means that the party, assisted or unassisted, who wins against an assisted litigant, is guaranteed that the reasonable costs in his favor will be paid, and that he will not be left, as in the past, with a pyrrhic victory against a man of straw.

The appraisal which this article has tried to present of a great and far-

13 Tbid. As regards the figures of the applicants to whom aid was given during the year 195051 , the Noble Lord announced that: "No fewer than 12,500 were required to contribute sums of between $£ 10$ and $£ 50$, and no fewer than 5,800 sums of $£ 50$ to $£ 100$. A small number of some hundreds were required to contribute an even larger sum. So your Lordships will see," he added, "that, in the majority of these State-aided cases, the litigant has to make some contribution himself. For that reason, he is not inclined to pursue his claim unless he genuinely believes in it." 
seeing act of national responsibility cannot be concluded, however, without deprecating the causes which have deferred the operation of some of the most valuable portions of the original scheme. Although the net saving by the government on the postponed services is estimated at only one million pounds for the current year, this decision means that, for the time being, at least, there will be no legal aid available, other than the existing rules permit, in (a) County Courts; (b) Magistrates Courts, as regards civil matters; (c) Coroner's Courts; and (d) Criminal Courts. Moreover, the proposed nation-wide Legal Advice Service must wait.

Such is the price of rearmament for a country which-after two major World Wars have deprived it of most of its overseas markets and investments-has no reserves of money or materials left on which to carry out the long-awaited social reforms that years of past neglect and economic decline have made long overdue. There is no call, therefore, to explain further these later installments of the completed scheme--except, perhaps, to point the obvious moral that the beneficent advance of justice within any national community today would seem to depend on the application of the same precepts of law-abidingness to the human Community as a whole. The rule of right cannot run in our domestic affairs, so long as nations practise the anarchy of might in world affairs. Can we discover, in time, how best to establish and extend that truly World Law, which is the only sure foundation for all other legal reform? For the English, at least, that is no fanciful question. 